\title{
Cutaneous Melanoma Clinical TNM
}

\section{Finding v8}

National Cancer Institute

\section{Source}

National Cancer Institute. Cutaneous Melanoma Clinical TNM Finding v8. NCI Thesaurus. Code C136893.

A clinical finding about one or more characteristics of cutaneous melanoma, following the rules of the TNM AJCC V8 classification system. 